\title{
A new subspecies of large-eared pika, Ochotona macrotis (Lagomorpha: Ochotonidae), from the Eastern Himalaya
}

\author{
Andrey A. Lissovsky*, Molly McDonough, Nishma Dahal, Wei Jin, \\ Shaoying Liu, Luis A. Ruedas
}

\begin{abstract}
We examined 212 complete sequences of the cytochrome $b$ gene for all pika species (Lagomorpha: Ochotona) as well as 250 skulls of pikas from the eastern Himalayan region. The results of our analyses suggest that a new and distinct subspecies of large-eared pika - Ochotona macrotis gomchee ssp.n. occurs in Bhutan. Our phylogenetic analyses indicate that this subspecies holds a sister-taxon relationship to other $O$. macrotis. The cranial shape of $O . m$. gomchee ssp.n. is similar to that of remaining O. macrotis; pelage colouration and ear length differentiate $O$. m. gomchee ssp.n. from all other representatives of $O$. macrotis. We hypothesize that pikas from the Great Bend of the Tsangpo River, which were previously assigned to $O$. forresti, in fact belong to $O$. macrotis; the correct name for that particular subspecies is therefore amended to $O . m$. duoxionglaensis. The distributional ranges of $O$. m. gomchee ssp.n. and $O$. $m$. duoxionglaensis are hypothesized to be separated by a broad matrix of unsuitable habitats. How to cite this article: Lissovsky A.A., McDonough M., Dahal N., Jin Wei, Liu Shaoying, Ruedas L.A. 2017. A new subspecies of large-eared pika, Ochotona macrotis (Lagomorpha: Ochotonidae), from the Eastern Himalaya // Russian J. Theriol. Vol.16. No.1. P.30-42. doi: 10.15298/rusjtheriol.16.1.03
\end{abstract}

KEY WORDS: Ochotona macrotis, Ochotona forresti, Himalaya, cytochrome $b$, morphology.

Andrey A. Lissovsky [andlis@zmmu.msu.ru], Zoological Museum of Moscow State University, Bolshaya Nikitskaya 6, Moscow 125009, Russia; Molly McDonough [McDonoughM@si.edu], Division of Mammals, Smithsonian Institution, MRC 108,Washington, DC 20013-7012,USA; NishmaDahal [nishmad@ncbs.res.in, dahal.nishma@gmail.com], National Centre for Biological Sciences, TIFR, Bellary Road, Bangalore, India 560065; Manipal University, Manipal-576104, Karnataka, India; Wei Jin [58683348@qq.com], ShaoyingLiu [shaoyliu@163.com], Sichuan Academy of Forestry, Chengdu 610081, China; Luis A. Ruedas [ruedas@pdx.edu], Department of Biology and Museum of Vertebrate Biology, Portland State University, 1719 SW 10 th Ave., Portland, Oregon 97201-0751, USA

\section{Новый подвид большеухой пищухи Ochotona macrotis (Lagomorpha) из восточных Гималаев}

\author{
А.А. Лисовский*, М. Макдоно, Н. Дахал, В. Цзинь, Ш. Лю, Л.А. Руэдас
}

РЕЗЮМЕ. Мы исследовали 212 полных последовательностей гена цитохром Б всех видов пищух (Lagomorpha: Ochotona) и 250 черепов пищух из восточных Гималаев. В результате анализа обнаружен новый подвид большеухой пищухи - Ochotona macrotis gomchee ssp.n. из Бутана. Этот таксон занимает сестринское положение к остальным O. macrotis. Форма черепа O. m. gomchee ssp.n. сходна с остальными $O$. macrotis; по окраске шкуры и длине уха $O$. $m$. gomchee ssp.n. отличается от остальных представителей O. macrotis. Мы предполагаем, что пищухи из петли р. Брахмапутра, которых ранее относили к $O$. forresti, также принадлежат O. macrotis; то есть корректное название этого подвида $O . m$. duoxionglaensis. Предполагается, что области распространения O. m. gomchee ssp.n. и O. m. duoxionglaensis разделены широкой полосой непригодных местообитаний.

КЛЮЧЕВЫЕ СЛОВА: Ochotona macrotis, Ochotona forresti, Гималаи, цитохром Б, морфология.

\section{Introduction}

Individual species of petrophilous pikas (Ochotona sp.) are usually restricted to narrow and species specific altitudinal and ecological bands (Smith et al., 1990). Mountainous landscapes with deep gorges or glaciers can isolate otherwise continuous habitats, resulting in fragmentation of populations. Complex topographic relief can therefore have negative impacts on individu-

* Corresponding author als' dispersal, hence influence species distributions, especially of high altitude and montane species. The topography of the Eastern Himalaya region (see Material and methods section for definition of the area) is quite complex (Fig. 1). Three mountain systems: Himalayas, Hengduan Mountains, and Transhimalayan Range Nyenchen Tanglha, meet within a tightly circumscribed geographic area, bisected by the Tsangpo Gorge.

The Eastern Himalaya is not very well studied especially in terms of small mammals. This is reflected in the sparse number of pika specimens from Bhutan and the Indian state of Arunachal Pradesh represented in 


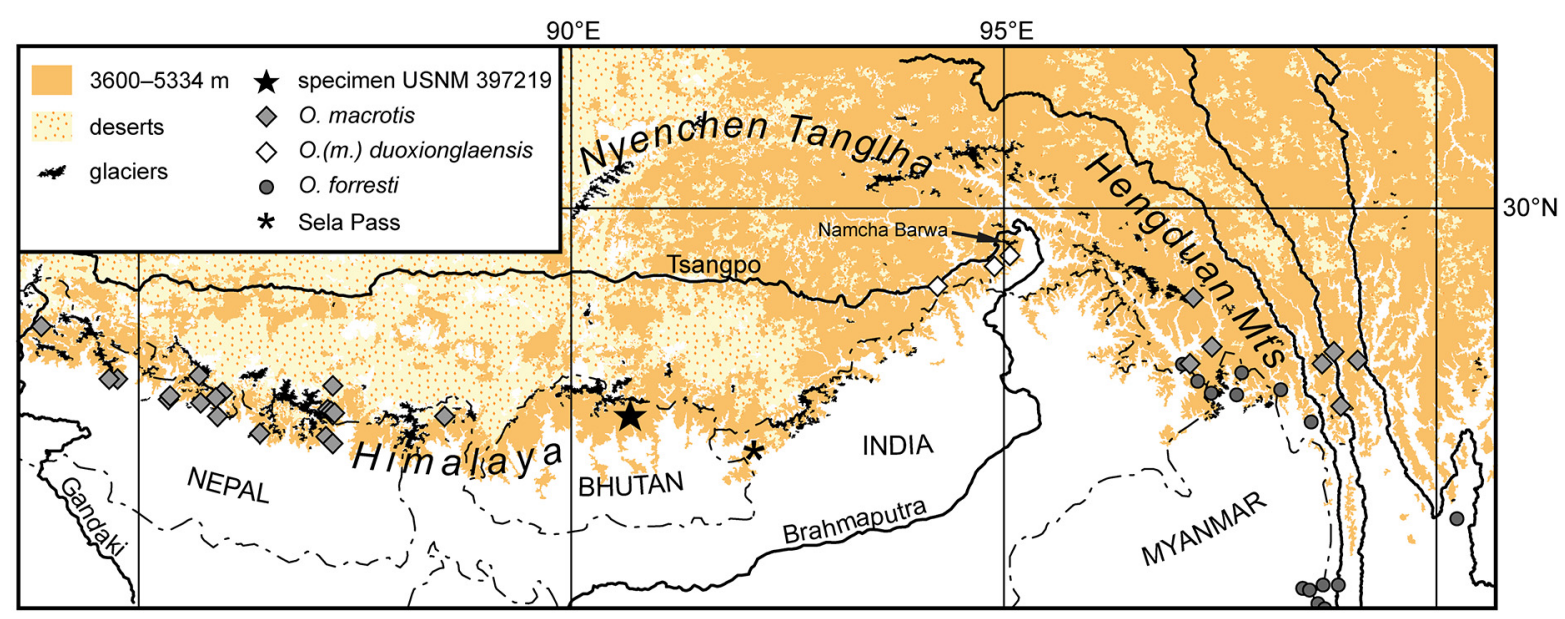

Fig. 1. Map of the area under study in this work. Altitudinal range suitable for O. macrotis and flat high altitude deserts are shown. Cartographic symbols show localities of studied cranial material. Headwaters of Chamka Chhu, where specimen USNM 397219 was collected, is marked with a star. Sela Pass is marked with asterisk.

museum collections. One of these specimens, housed in the Smithsonian Institution's National Museum of Natural History, has previously been cited as a remote record of $O$. forresti Thomas, 1923 (Smith et al., 1990; Hoffmann \& Smith, 2005). However, O. forresti is currently known only from the Hengduan Mts, therefore the validity of specimens ascribed to $O$. forresti originating from the Eastern Himalaya remain uncertain (Ge et al., 2012). In this paper we investigate the taxonomic identity of the specimen from the Smithsonian Institution. We also include all the data available for petrophilous pika species reported from the Eastern Himalaya.

\section{Materials and methods}

\section{Morphological analyses}

We analysed all available museum specimens of Ochotona within the region bounded to the west by the Kali Gandaki River, the acknowledged border between western and eastern Himalaya, and southern mountain ranges of Hengduan Mts in the east (Fig. 1). To the south, our region of interest is bounded by the natural southern limit of pikas' distribution, while the northern limit was artificially selected to be constituted by portions of the Tibetan Plateau adjoining the Eastern Himalaya south of Tsangpo River. We combined two species: O. sikimaria Thomas, 1922 and O. thibetana (Milne-Edwards, 1871) under the conventional name "O. thibetana s.l." These two species are very similar in morphology (Dahal et al., 2017), so such combination should not affect our results. Discrimination between these latter two species is in need of a more focused investigation.

Our morphological sample included 285 skulls (Appendix 1), 35 of which were juvenile hence not included in the main analysis (see below); we examined ap- proximately 400 skins. Specimens examined were housed in the collections of the Smithsonian Institution's National Museum of Natural History (USNM, Washington, D.C.); Institute of Zoology, Chinese Academy of Science (BIZ, Beijing); Kunming Institute of Zoology (KIZ, Kunming); Natural History Museum (NHMUK, London); Northwest Institute of Plateau Biology of Chinese Academy of Science (NWIPB, Xining); Zoological Survey of India (ZSI, Kolkata); Sichuan Academy of Forestry (SAF, Chengdu); Field Museum of Natural History (FMNH, Chicago); Museum für Naturkunde (ZMB, Berlin); American Museum of Natural History (AMNH, New York); Museum of Vertebrate Zoology (MVZ, Berkeley); Zoological Museum of Moscow University (ZMMU, Moscow), and Zoological Institute of Russian Academy of Sciences (ZIN, Saint Petersburg).

Following Lissovsky (2014), twenty measurements were taken on each skull using calipers to an accuracy of $0.01 \mathrm{~mm}$. Measurements included: condylobasal length, length of palatine foramen, upper diastemal length, alveolar length of maxillary toothrow, rostral length (from the anterior edge of premaxillary bones to the posterior edge of maxillary toothrow alveoli), length of auditory bulla, distance between auditory bullae, length of the suture between parietal bones, length of the suture between frontal bones, maximal length of orbit (OL), maximal width of orbit (OW), interorbital constriction, width of the rostrum between maxillary openings, zygomatic breadth (ZB), postorbital constriction (PC), maximal width between lateral edges of auditory bullae, general skull height, skull height on the level of auditory bullae, general height of mandible, height of mandible behind the toothrow. All calculations were carried out on $\log _{10}$-transformed measurements in order to linearize age variation (Mina \& Klevezal, 1976). 
Our material included only three geographic samples containing both juvenile and adult pikas across all species. We were thus unable to correct for age bias, as in previous studies (Lissovsky, 2014). Juveniles were therefore excluded from the analysis in order to minimise age bias. A variant of factor analysis was applied as an ordination method: first, the eigenvectors of the between group covariance matrix (with identifiers of single-species geographical samples as groups) were calculated. Secondly, the initial data matrix was multiplied with the matrix of the eigenvectors. Thus, the initial data were rotated into the space of intergroup variation without distortion of the initial space (Obolenskaya et al., 2009). The analysis was performed twice: first using all species from the studied region, and secondly using O. macrotis (Günter, 1875), $O$. roylii (Ogilby, 1839), O. gloveri Thomas, 1922, and $O$. forresti duoxionglaensis Chen et Li, 2009 only. Data were processed using standard algorithms implemented in STATISTICA 13.0 (Dell Inc., 2015) and several algorithms written by AAL in Statistica Visual Basics.

\section{Genetic analysis}

Complete sequences of the cytochrome $b$ (cyt $b$ ) gene $(1140 \mathrm{bp})$ were analysed from 198 specimens of all pika species except $O$. iliensis $\mathrm{Li}$ et $\mathrm{Ma}, 1986$, for which there is no complete sequence available (Appendix 2). We retrieved 207 sequences from GenBank and generated five sequences de novo. One sequence was generated from a single claw plus terminal phalange from specimen USNM 397219 (GenBank accession KX989538). Four sequences were obtained from fresh tissues preserved in ethanol. These included three specimens of $O$. forresti (SAF 07680, SAF 07668, SAF 07679) and one specimen of O. macrotis (SAF 07637) that were collected in Ridong, Chayu, Xizang, China (GenBank nos. KX989537, KU359628, KU359627, and KX989536, respectively). Fourteen taxa of leporids were used as outgroup, following Lissovsky (2014).

Extraction. For the single claw sample, extraction methods followed McDonough et al. (in prep.) for extracting DNA from mammalian claws. Extraction and library preparation were performed in an isolated room used exclusively for ancient DNA extractions at the Smithsonian Conservation Biology Institute, Center for Conservation Genomics. Initially, the claw was rinsed with $0.5 \%$ fresh bleach solution following Campos \& Gilbert (2012). The sample was then rinsed with 70\% ethanol, and placed in a sterile $2 \mathrm{~mL}$ screw-cap tube filled with $1.5 \mathrm{~mL}$ of HPLC-grade water. The sample was rinsed in water for $72 \mathrm{~h}$, changing the water every 12 hours to avoid any bleach carry-over. The claw was then dried with a sterile Kimwipe and cut into several sections using a sterile scalpel blade. The sample was placed into a new sterile $2 \mathrm{~mL}$ screw-cap tube with rubber gasket and $600 \mu \mathrm{L}$ of extraction solution were added following McDonough et al. (in prep.). Samples were then placed on a rotator in a $37^{\circ} \mathrm{C}$ incubator for 72 $\mathrm{h}$, adding Proteinase $\mathrm{K}$ and DTT as needed until the toenail was completely dissolved. The sample was extracted with phenol twice, with chloroform once, and finally DNA was collected using an Amicon filter following Leonard et al. (2000). The DNA sample was quantified using a Bioanalyzer High Sensitivity Kit (Agilent).

For samples preserved in $95 \%$ ethanol, total genomic DNA was extracted from muscle tissues using the Qiagen DNeasy Blood and Tissue Kit (Qiagen, Germantown, MD, USA). Double-stranded DNA amplifications of complete cyt $b$ were performed for each individual with universal primers L14724 (Pääbo \& Wilson, 1988), L15408 and H15915R (Irwin et al., 1991), and H15149 (Kocher et al., 1989).

Library preparation. Because historical DNA is typically fragmented, we did not shear the claw DNA extract as is generally done during the first step in library preparation. Instead, $40 \mu \mathrm{L}$ of DNA extracted from claw were purified using $5 \mathrm{X}$ magnetic bead purification following Rohland \& Reich (2012), then prepared using a KAPA LTP library preparation kit with beads for Illumina platforms following the manufacturer's protocol with $1 / 4$ reactions. Dual indexing PCR (Kircher et al., 2012) was performed with Nexterastyle indices using KAPA Hifi with an initial denaturation of $98^{\circ} \mathrm{C}$ for 45 seconds followed by 18 cycles of $98^{\circ} \mathrm{C}$ for 15 seconds, $60^{\circ} \mathrm{C}$ for 30 seconds, $72^{\circ} \mathrm{C}$ for 60 seconds, with a final extension of $72^{\circ} \mathrm{C}$ for 5 minutes. The reaction was purified using $1.8 \mathrm{X}$ magnetic beads and visualized on a $1.5 \%$ agarose gel.

High-throughput sequencing. The toenail library was quantified using a Bioanalyzer High Sensitivity Kit and Qubit high sensitivity assay. The historic sample was pooled in an equal molar ratio with samples for another project. Samples were run using a 2 x150 MiSeq Reagent Kit v3 on a MiSeq platform at the Smithsonian Conservation Biology Institute, Center for Conservation Genomics.

Analyses. Paired-end reads were merged using PEAR v0.9.4 (Zhang et al., 2014). Adapter sequences were removed using Cutadapt v1.4.2 (Martin, 2011). Prinseq v0.20.4 (Schmieder \& Edwards, 2011) was used to remove reads with mean quality score $<20$ and PCR duplicates. Reads were mapped to the Ochotona princeps mitochondrial genome (GenBank no. NC00538.1) using the BWA-MEM algorithm implemented by BWA v0.7.10 (Li \& Durbin, 2009). The SAM output was visualized in Geneious v8.1.6 and the cyt $b$ gene sequence extracted.

A total of 1377221 reads were merged in PEAR (Zhang et al., 2014). After adapter cutting and quality filtering, 1315406 reads were mapped to the reference sequence. After mapping to the $O$. princeps (Richardson, 1828) mitochondrial genome, we recovered approximately $100 x$ coverage of the complete mitochondrial genome and approximately $165 x$ coverage of the cyt $b$ gene.

Amplification and sequencing in alcohol-preserved samples. PCR amplification was performed in a reac- 
tion mixture of $25 \mu \mathrm{l}$ containing $5 \mathrm{pM}$ of each primer, $100 \mathrm{iM}$ of each dNTP, 2.5 il 10 X LA PCR Buffer, 1.25 $\mathrm{U}$ of TaKaRa LA Taq ${ }^{\circledR}$ (TaKaRa Biotechnology Co., Ltd., Dalian), and 50-100 ng genomic DNA. The PCR amplification reaction was performed with initial denaturation at $95^{\circ} \mathrm{C}$ for $5 \mathrm{~min}$, followed by 34 cycles of 30 $\mathrm{s}$ at $94^{\circ} \mathrm{C}$, annealing for $50 \mathrm{~s}$ at $48-50^{\circ} \mathrm{C}$, and a $1.5 \mathrm{~min}$ extension at $72^{\circ} \mathrm{C}$, with a final extension at $72^{\circ} \mathrm{C}$ for 10 $\min$.

Amplified PCR products were checked electrophoretically on a $1 \%$ agarose gel and visualized with ethidium bromide-staining to verify PCR quality. The fragments were sized using the molecular weight marker DL2,000 (TaKaRa). Purification of PCR products was conducted with a MiniBEST DNA Fragment Purification Kit v.3.0 (TaKaRa). Direct sequencing was performed using the Big Dye 3.1 Terminator cycle sequencing kit (Applied Biosystems, Foster City, CA, USA) according to the manufacturer's instructions. Nucleotide sequences were recovered using an ABI PRISM 3730 sequencer (Applied Biosystems).

Phylogenetic analyses. Maximum likelihood genetic distances were calculated using Treefinder (Jobb, 2011). The Akaike information criterion was used to determine the most appropriate model of molecular evolution in the Propose Model dialog. Standard deviations of ML distances and bootstrap values were calculated using 1000 replicates.

A Bayesian analysis was performed in MrBayes 3.2.5 (Ronquist et al., 2012) run for 23000000 generations; and implementing two runs with five independent chains with a heating parameter of $0.04,25 \%$ burn in, a sampling frequency of 5000 , under the GTR $+\mathrm{I}+\Gamma$ model separate for each codon position following Lanier and Olson (2009). Stationarity was assessed in Tracer v1.6 (Rambaut et al., 2014). The heating parameter was selected in preliminary runs following Ronquist et al. (2011). Maximum clade credibility trees were constructed using TreeAnnotator v2.2.1.

\section{Distributional modelling}

Since specimen USNM 397219 was collected at high altitude (ca. $4010 \mathrm{~m}$ asl) near a glacier, and constitutes the sister taxon to $O$. macrotis sensu stricto (see below, results), which also is a high altitude species, we calculated and mapped the $95 \%$ confidence interval of the altitudinal distribution of $O$. macrotis (3600-5334 $\mathrm{m}$ asl, $n=29)$. We also classified landscapes of the region under consideration herein into five discrete categories using generalized average monthly MODIS data for June 2004 (http://glcf.umd.edu/data/modis/). One of the categories roughly corresponded to flat high altitude deserts after comparison with topographic maps of 1:500 000 scale. The value of annual precipitation for the territory under this category was $369 \pm 249 \mathrm{~mm}$ (average $\pm \mathrm{SD}$ ). Annual precipitation values and altitudes were taken from WorldClim (Hijmans et al., 2005). All calculations were carried out in Scanex Image Processor v. 4.2.14. We used Classification-Unsu-
pervised-IsoData algorithm with 50 iterations for classification. The number of categories was determined manually to better fit flat, high altitude deserts.

\section{Results}

Museum collections across the world house seven species of pikas from the region: $O$. macrotis, $O$. roylii, O. gloveri, O. forresti, O. nubrica Thomas, 1922, O. thibetana s.1., and O. curzoniae (Hodgson, 1858). To our knowledge, only two museum specimens are known from Bhutan: the individual under study here (USNM 397219) and a specimen of $O$. thibetana s.l. (USNM 395248). The adjacent territory of the Indian state of Sikkim is inhabited by $O$. macrotis and $O$. thibetana s.l.; $O$. roylii lives in westernmost part (farthest from Bhutan) of Sikkim. There exist no specimens of pikas with an intact skull, i.e., suitable for identification, from the eastern parts of the Himalaya, within the Indian state of Arunachal Pradesh. Two burrowing pika species, $O$. nubrica and $O$. curzoniae, are widely distributed on the "flat" part of the Tibetan Plateau in the region under discussion, but do not penetrate the mountain slopes of the Himalaya in its eastern part and are never found on its southern slope. Ochotona gloveri does not occur in the Himalayas, instead exclusively inhabiting the Hengduan Mts. These mountains also contain the distributional range of $O$. forresti; $O . f$. duoxionglaensis inhabits the easternmost mountains of Himalayas, the Namcha Barwa Mountains just inside the Great Bend of the Tsangpo River (Fig. 1; Chen \& Li, 2009; Ge et al., 2012). The broadest distribution among petrophilous species in the region is that of $O$. macrotis which, however, have never been recorded from the territory of Bhutan.

Specimen USNM 397219 is a subadult pika with rounded crests on the angular process of the mandible; general proportions of the skull are similar to those of adult pika (Lissovsky, 2004). Measurements (from the museum tag) are: total length $155 \mathrm{~mm}$; hind foot 20 $\mathrm{mm}$, ear length $26 \mathrm{~mm}$, and body weight $130 \mathrm{~g}$. The skull of the specimen lacks one auditory bulla and has no frontal openings. Incisive and palatal foramina are confluent; this opening is not pear-shaped, as in $O$. forresti (Feng \& Zheng, 1985; Smith et al., 1990; Ge et al., 2012). The proximal half of the nasals is wide with parallel outer parts, as characteristic for O. macrotis (Fig. 2). The cranial shape of this specimen is similar to that of $O$. macrotis, O. roylii, and O. gloveri (Fig. 3), being notably different from the burrowing species $O$. nubrica, O. thibetana, and O. curzoniae. More detailed study (Fig. 4) shows that Bhutanese specimen occurs on the periphery of the cloud of points representing the multivariate morphometric cranial variation of $\mathrm{O}$. $\mathrm{mac}$ rotis.

Specimens of $O$. forresti s.str. are distinctly segregated in morphospace from the specimen under discussion and also do not intersect $O$. macrotis (Fig. 3). Unlike $O$. macrotis, the nasal bones of $O$. forresti con- 

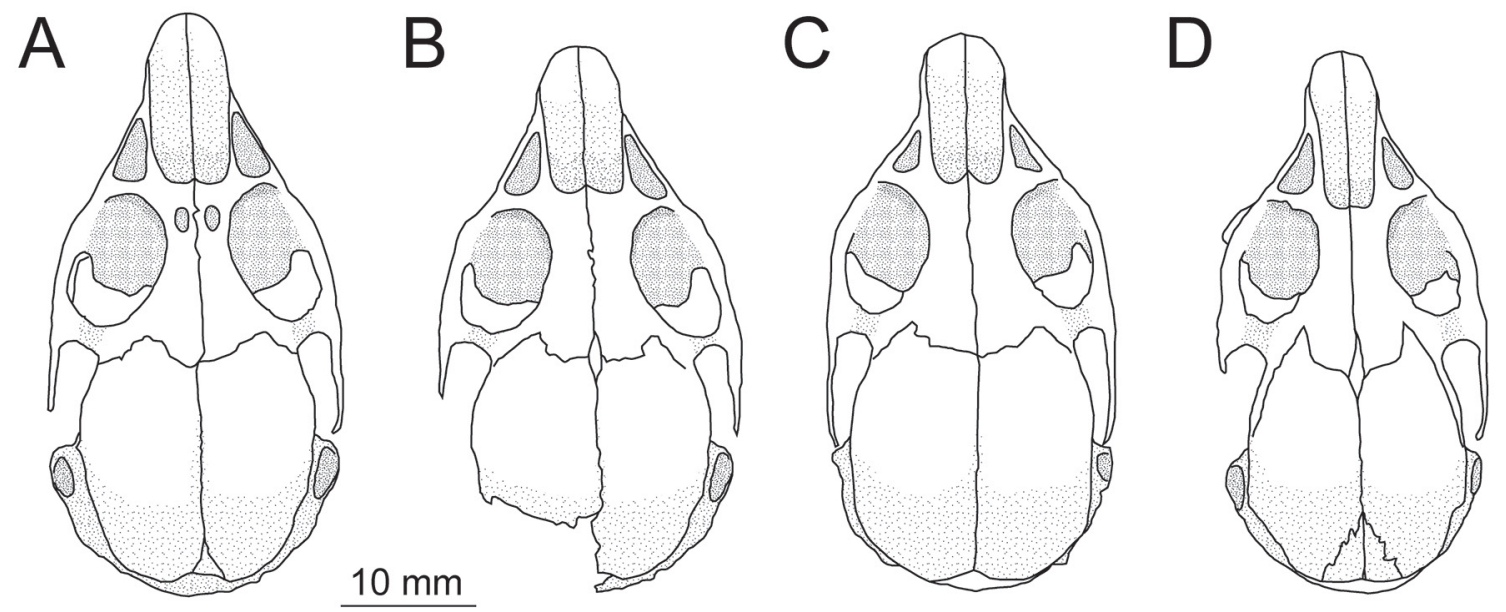

Fig. 2. Skulls of pikas from the eastern Himalaya. A - O. macrotis, Chayu, Xizang, BIZ 26854; B - specimen from Bhutan, USNM 397219; C - holotype of duoxionglaensis, NWIPB 77139; D - O. forresti, Gongshan, Yunnan, KIZ 73148.

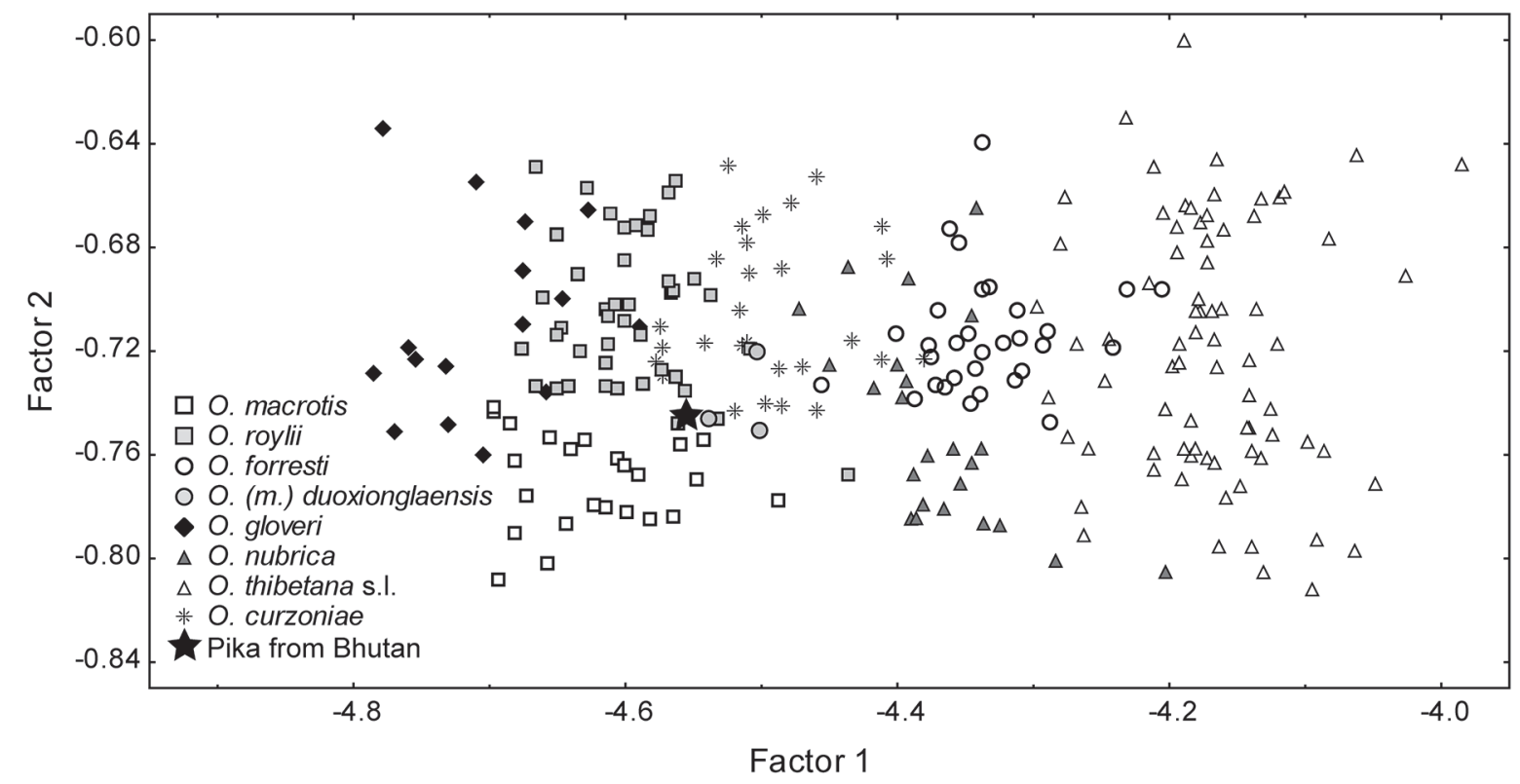

Fig. 3. Distribution of all the available pika specimens from the eastern Himalayas and Hengduan Mts in the space of maximized between-sample craniometric differences.

verge in proximal direction (Fig. 2). Specimens of $O . f$. duoxionglaensis are located closer to O. macrotis than to $O$. forresti in two-dimensional morphospace (Fig. 3). The caudal part of the nasal bones in $O . f$. duoxionglaensis are wider, with subparallel labial margins (Fig. 2). Cranial differences between the Bhutanese specimen and $O . f$. duoxionglaensis also are manifested in the broader skull and larger orbit in the former: Bhutanese - ZB $21.6 \mathrm{~mm}$, PC $15.0 \mathrm{~mm}$, OL $10.4 \mathrm{~mm}$, OW $8.3 \mathrm{~mm}$; O.f. duoxionglaensis - ZB 20.5-21.3 mm, PC 14.1-14.8 mm, OL 9.9-10.1 mm, OW 8.0-8.2 mm.
Fur coloration of the Bhutanese specimen (Fig. 5) differs notably from all representatives of $O$. macrotis. The dorsal side of the specimen is dark grey speckled with black; ventral parts are grey. The collar is sandy; a patch of long hairs behind the ears is silver, while the eye patches are grey. To all appearances, the specimen is in winter fur. In contrast, the winter pelage of $O$. macrotis is light grey or sandy with no collar or black speckling. Another notable difference relative to $O$. macrotis is absence of a chestnut patch on the forehead of the Bhutanese specimen. Stark contrast in the chest- 


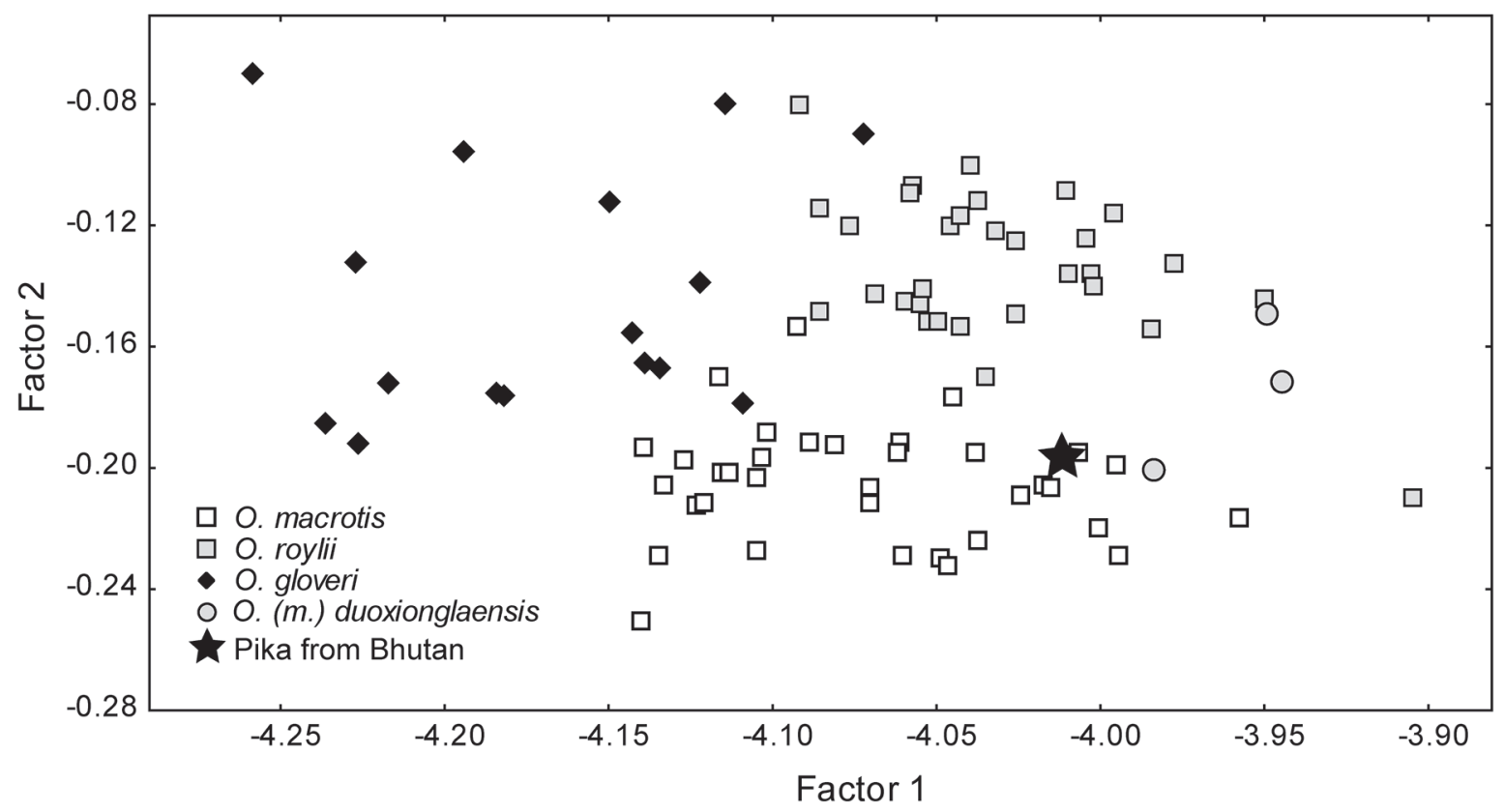

Fig. 4. Distribution of Ochotona macrotis, $O$. roylii, $O .(\mathrm{m}$.$) duoxionglaensis, and O$. gloveri specimens from the eastern Himalayas and Hengduan Mts in the space of maximized between-sample craniometric differences.

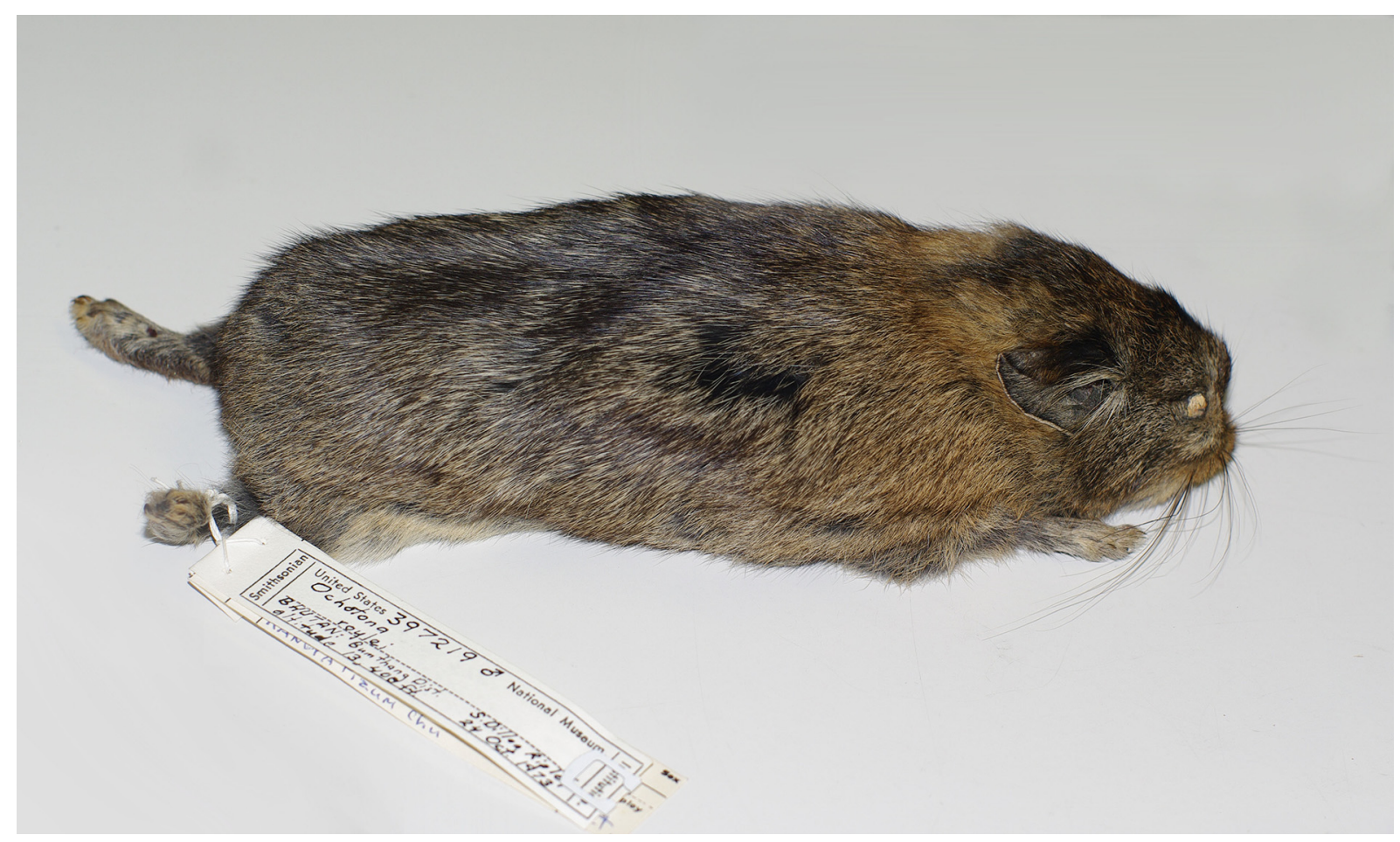

Fig. 5. Skin of the specimen USNM 397219 from headwaters of Chamka Chhu, Bhutan.

nut forehead patch is characteristic in all populations of $O$. macrotis across its range. Some specimens of $O . m$. chinensis Thomas, 1911, which is distributed in the Hengduan Mts. well east of Bhutan and the Great Bend of the Tsangpo River, are somewhat darker. However, a chestnut forehead patch remains clearly visible even in winter pelage. In the Bhutanese specimen, the forehead does not differ from surrounding skin. The length of the ear $(26 \mathrm{~mm})$ is in the lower limit of the variation for $O$. macrotis: mean \pm SD for the latter is $29.2 \pm 3.8 \mathrm{~mm}$ $(n=30)$; $\min -\max 21-35 \mathrm{~mm} ; 95 \%$ confidence interval $27.8-30.6 \mathrm{~mm}$. 

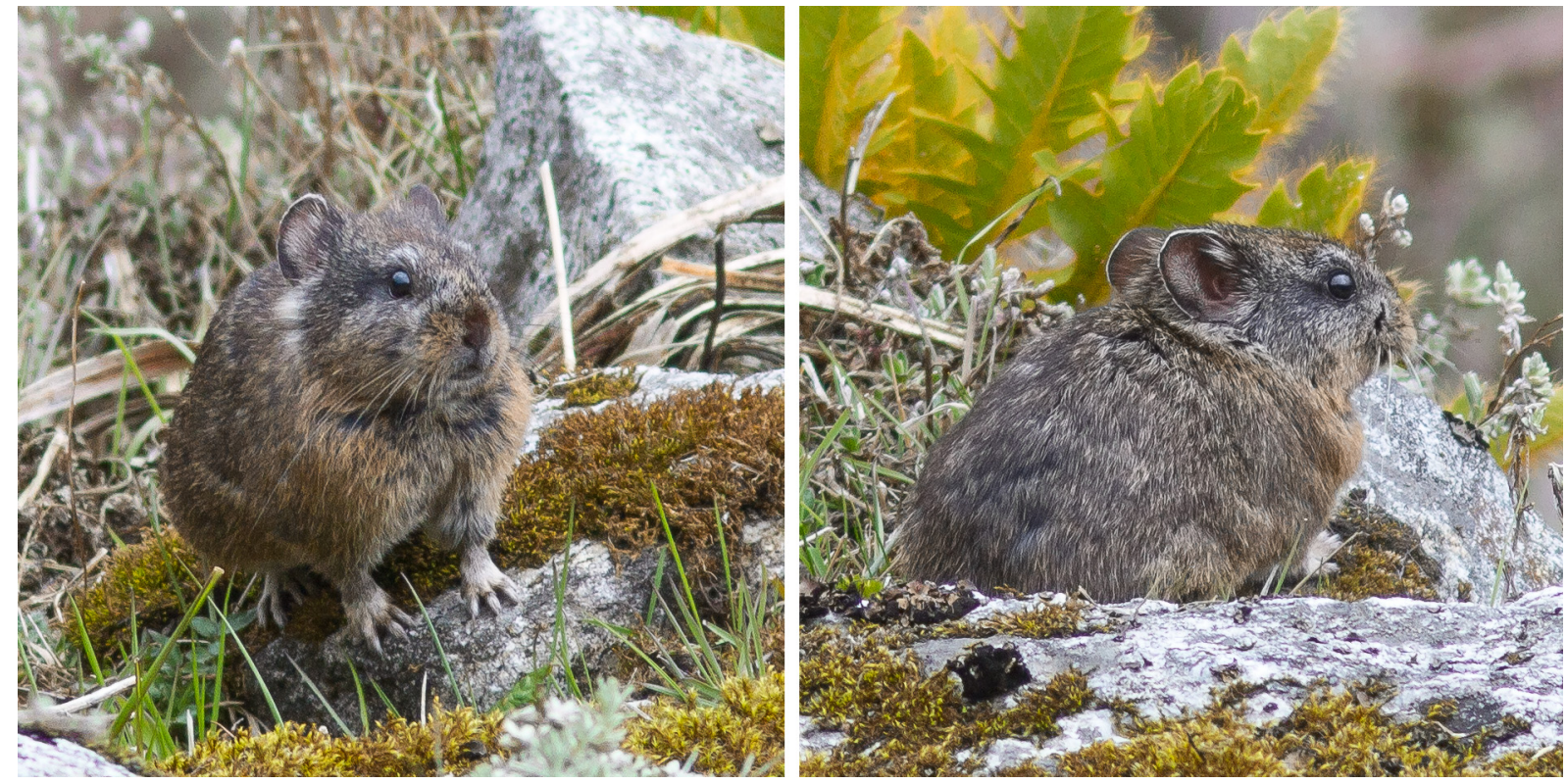

Fig. 6. Pika near Sela Pass, Arunachal Pradesh, India. Photo by Benjamin Schweinhart.

Unlike $O$. macrotis, which all have a readily apparent dark band along the edge of lighter inner surface of the ear, the Bhutanese specimen has an inner ear surface that is dark. The Bhutanese pika's ear is more similar to that of O. alpina (Pallas, 1773) or O. hyperborea (Pallas, 1811): dark with a very narrow white stripe along the very edge. This feature could however be an individual character of the specimen. The reason for sowing such doubt lies in two photos made by Benjamin Schweinhart in Sela Pass (Arunachal Pradesh, India: $27.5^{\circ} \mathrm{N} ; 92.1^{\circ} \mathrm{E}, 4202 \mathrm{~m}$ ) on 23 May 2015 (Fig. 6). Sela Pass and the headwaters of Chamka Chhu, where our Bhutanese specimen was collected, lie on the same aspect of the Great Himalaya Range, and the straight-line geographic distance between the two points is ca. $148 \mathrm{~km}$. The distance measured within the selected altitudinal band containing habitat likely for $O$. $m a$ crotis is about $249 \mathrm{~km}$. The animal on the photos have a clear macrotis-like dark band along the ear edge. However, other pelage features are similar to Bhutanese specimen: there is no chestnut patch on the forehead, the dorsal fur is dark speckled with black, and there are silver hairs behind the ears, which are of moderate length. The underparts of the animal from Sela Pass are rufous, not grey, which could be an attribute of summer fur.

Skins of $O . f$. duoxionglaensis have a similar pattern but distinct colouration. The dorsal parts in specimens collected in August and early September are brown, the head and shoulders are grey, the head is darker, collar lighter, and there is no chestnut forehead patch. One specimen, NHMUK 48.310, originally identified as "O. roylii chinensis" from Nam La, south of Namcha Barwa, has a dark grey hind head, but the cheeks and forehead are more similar to O. macrotis: cheeks are lighter and the forehead is brown. Many silver hairs are dispersed in the grey of the head and shoulders in all specimens; the ventral parts also are grey. Ears are without dark edge band. Ear lengths are 21, 23, 23, and 24 (from museum labels). Specimens seem to be in summer fur, probably, partly in moult.

Specimens of $O$. forresti s. str. have very different colouration from our Bhutanese specimen and from $O$. $f$. duoxionglaensis, depending on the season and location. There are three populations of $O$. forrest $i$ : Lijiang (O. f. forresti); environs of Pianma, Lushui County of Yunnan Province and adjacent Myanmar (O.f. osgoodi Anthony, 1941); and northernmost Myanmar and adjacent Gongshan County of Yunnan Province, China, and Chayu County of Xizang Province, China (O.f. gaoligongensis Wang, Gong et Duan, 1988) (Fig. 1). The holotype of $O$. f. forresti, an individual in summer fur, is agouti brown with some grey on the head. Specimens of $O$. f. osgoodi in winter fur look similar to the $O . f$. forresti: brown agouti with grey head. Summer specimens are a more vivid brown heavily speckled with black. Winter specimens of $O . f$. gaoligongensis (situated closest to Himalayas) are also agouti brown with a grey head. Summer fur is vivid reddish-brown. The moult touches the head during its the last stage, such that many specimens in collections have a reddish head and brown body. All subspecies of $O$. forresti s. str. have light grey or ochraceous ventral parts.

In conclusion, winter specimens of $O$. forresti, $O . f$. duoxionglaensis (allowing that September specimens have some aspects of winter fur), and the Bhutanese specimen, have no notable distinctive markings in colouration. All have a brown or agouti grey body, with the head of a different colour. Summer specimens of $O$. forresti, especially of westernmost $O$.f. gaoligongensis, clearly differ from $O . f$. duoxionglaensis and the Bhutanese specimen by the presence of bright brown hairs. 


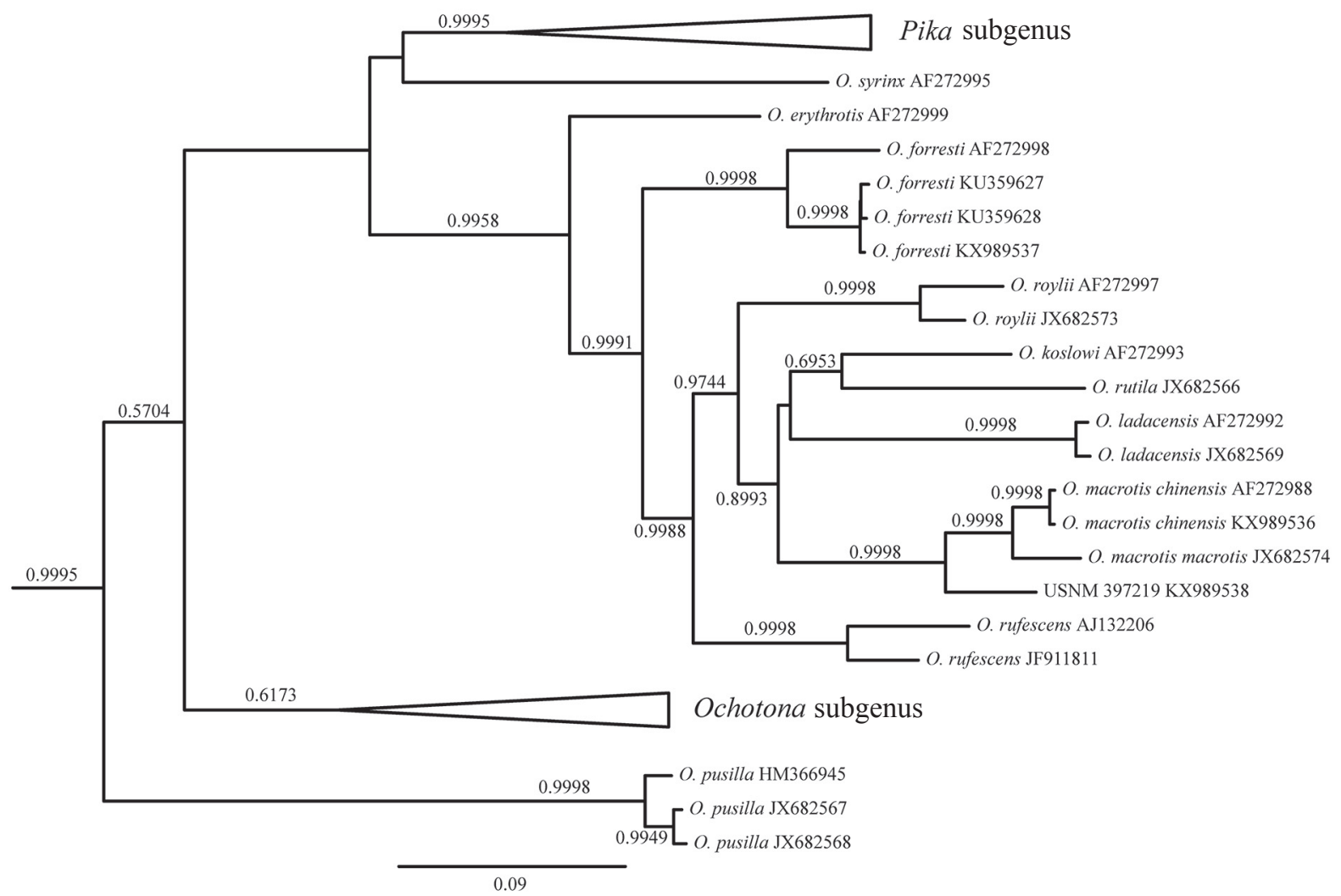

Fig. 7. Maximum clade credibility tree of Bayesian analysis based on cytochrome $b$ sequences. Numbers on branches indicate Bayesian probabilities. Outgroup not shown.

Table. Genetic distances between pikas taxa calculated on the basis of cytochrome $b$ gene.

\begin{tabular}{|l|c|c|}
\hline \multicolumn{1}{|c|}{ Taxa } & Mean \pm SD & Range \\
\hline O. macrotis-Bhutanese specimen & $8.2 \pm 2.9$ & \\
\hline O. hyperborea-O. mantchurica & $8.7 \pm 3.1$ & \\
\hline between O. macrotis clades & $4.1 \pm 1.5$ & \\
\hline between O. roylei clades & $5.0 \pm 1.9$ & \\
\hline between O. forresti clades & $6.6 \pm 2.0$ & \\
\hline between O. rufescens specimens & $8.1 \pm 2.3$ & \\
\hline between O. princeps clades & $6.8 \pm 3.4$ & {$[4.3-9.7]$} \\
\hline between O. hyperborea clades & $6.0 \pm 2.1$ & {$[4.5-7.1]$} \\
\hline between O. curzoniae clades & $2.4 \pm 1.7$ & {$[0.5-4.4]$} \\
\hline interspecies Ochotona subgenus & $13.8 \pm 5.1$ & {$[8.9-16.6]$} \\
\hline interspecies Pika subgenus & $17.3 \pm 6.5$ & {$[5.5-23.2]$} \\
\hline interspecies Conothoa subgenus & $23.2 \pm 7.6$ & {$[16.6-30.0]$} \\
\hline
\end{tabular}

The Bhutanese specimen occupies a sister-taxon position to $O$. macrotis on the tree derived from the analysis of the mitochondrial cyt $b$ gene (Fig. 7). The genetic distance between the former specimen and $O$. macrotis is $8.2 \%$ (Table); other cyt $b$ interspecific distances also are listed in Table.

\section{Discussion}

The Bhutanese specimen appears to constitute a sister-taxon to $O$. macrotis based on the phylogenetic analysis of the cyt $b$ gene (Fig. 7). Cranial morphological features situate the specimen under study within the 
multivariate space limits of intraspecific variation of $O$. macrotis (Fig. 4). Based on congruence between morphological and mitochondrial datasets, we therefore consider that mitochondrial introgression is an unlikely scenario and consider the resulting tree topology (Fig. 7) to be accurate. However, pelage colouration and shorter ear length distinctly discriminate this specimen from all those of $O$. macrotis. Inference based on pelage therefore suggests that the Bhutanese specimen may constitute a distinct, undescribed taxon in the species group.

The genetic distance between this specimen and its sister taxon, $O$. macrotis, is about $8 \%$, which is twice the distance between subspecies of large-eared pika $(O$. macrotis) from the western Himalaya (O. m. macrotis) and Hengduan Mountains (O. m. chinensis; Table). Eight percent is comparable with interspecific distances within Ochotona and Pika subgenera, but lies within the magnitude of intraspecific variation in some well studied species such as $O$. princeps and $O$. rufescens. Ochotona macrotis belongs to subgenus Conothoa (Yu et al., 2000; Lissovsky, 2014), where interspecific distances are the largest among pikas (Table). Thus, the distance between the Bhutanese specimen and $O$. $\mathrm{mac}$ rotis is half that of other interspecific distances within Conothoa. Therefore, taking into account the range of interspecific distances in Conothoa, we recommend at this time considering the Bhutanese specimen to correspond to a taxon at the subspecific taxonomic level, as a subspecies of $O$. macrotis.

Although we have no genetic data from $O . f$. duoxionglaensis, we hypothesize that this taxon could possibly belong in $O$. macrotis rather than $O$. forresti. The pelage pattern is similar to that of the Bhutanese specimen under consideration herein, and different from $O$. forresti when undertaking comparisons of the summer pelage of both taxa. Morphological analysis of cranial characters, albeit on the basis of a highly limited sample, locates $O$. f. duoxionglaensis closer to O. macrotis than to $O$. forresti. The difference between $O$. f. duoxionglaensis and $O$. forresti $\mathrm{s}$. str. in the shape of palatal opening has been noted previously (Ge et al., 2012). The shape of nasal bones unites $O$. duoxionglaensis and $O$. macrotis. We also found that $O$. macrotis from Bhutan have shorter ears. Thus, O. duoxionglaensis is overall more similar to O. macrotis in morphology. An additional line of evidence that argues in favour of considering $O$. duoxionglaensis as a part of $O$. macrotis follows from their mutual distributions. The known distribution of $O$. duoxionglaensis covers the easternmost part of Himalaya, surrounded by the Great Bend of the Tsangpo River (Fig. 1). The Tsangpo Gorge possibly forms a barrier for high altitude pikas, separating the Himalayan populations $(O$. macrotis) from the Hengduan Mts. population (O. forresti s. str.).

If our hypothesis is correct and $O$. duoxionglaensis is a form close to $O$. macrotis, the name «O. duoxionglaensis» could be the senior synonym for pikas of the Eastern Himalaya. However, based on the morphologi- cal differences between the Bhutanese specimen and $O$. duoxionglaensis (see Results), we consider the differences between $O$. duoxionglaensis and the Bhutanese specimen to be of a subspecific level.

Distribution of potentially suitable habitats in Eastern Himalaya indirectly supports the hypothesis of isolated distribution of two pika taxa in the region (Fig. 1). Altitudinal restriction of habitat distributions is affected by the extensive glaciers and deserts in the higher altitudes of the Himalaya, potentially making the distribution of $O$. macrotis in the region consist of at least two isolated populations: that of Bhutan on the one hand, and that of the Great Bend of the Tsangpo River on the other. Thus, spatial contact between O. duoxionglaensis and Bhutanese taxon seems unlikely. Accordingly, we describe the Bhutanese taxon as:

Ochotona macrotis gomchee Lissovsky, ssp.n.

Holotype: male, USNM 397219, collected 24 of October 1973 by Sidney Dillon Ripley in Bhutan, Bumthang, Kangra Pizum Chhu, headwaters of Chamka Chhu ("Chu" in museum label), altitude ca. $4100 \mathrm{~m}$ (13400 ft.) asl (approximately $27.95^{\circ} \mathrm{N} ; 90.69^{\circ} \mathrm{E}$ ).

DIAGNOSIS: Pika of medium size (condylobasal length, $38 \mathrm{~mm}$; total body length, $155 \mathrm{~mm}$ ) with dark grey pelage speckled with black; collar sandy; ventral parts grey (Fig. 5). Incisive and palatal openings of skull widely confluent; proximal half of nasals wide, with parallel outer sides (Fig. 2 B).

COMPARISONS: Differs from O. macrotis in shorter ear, darker pelage speckled with black, and dark grey head without chestnut patch on the forehead. Differs from $O . m$. duoxionglaensis in wider skull and larger orbit.

ETYMOLOGY: The subspecific trivial epithet is a Bhutanese name for pikas.

We have no data on distribution of $O$. m. gomchee, however distribution of potentially suitable habitats and skins of museum specimens allow us to hypothesize that this taxon possibly extends its distribution towards the southern slope of Eastern Himalaya from East Sikkim to the westernmost part of Arunachal Pradesh. Distribution extending far to the east, in northern Arunachal Pradesh, is not likely as the southern slope lacks altitudinal range there required for an ecologically suitable environment.

The large eared pika, O. macrotis, is widely distributed across high mountain ranges of Inner and Central Asia (Smith et al., 1990; Hoffmann \& Smith, 2005). It inhabits alpine talus in the high altitude regions of Tianshan, Pamir, Karakoram, Kunlun, western Transhimalayas, Himalaya, and Hengduan Mts. Previous taxonomic discussions of $O$. macrotis have included debates on the phylogenetic position of pikas from the Hengduan Mts. (Feng \& Zheng, 1985; Smith et al., 1990; Hoffmann \& Smith, 2005; Lissovsky, 2014), which are darker in colouration and seem to be isolated geographically from Himalayan pikas. However, the 
taxonomy of pikas from the easternmost Himalaya has never been addressed. We found that the genetic distance between pikas from Bhutan and other O. macrotis is twice the magnitude of that between subspecies from the western Himalaya and Hengduan Mountains (Table). The pika specimen from Bhutan appears, based on our mitochondrial data, to constitute the ancestral lineage of $O$. macrotis (Fig. 7) whereas pikas from the western Himalaya (O. m. macrotis) and Hengduan Mts. (O. m. chinensis) are in contrast sister taxa. Thus it seems probable that the common ancestor for $O$. $\mathrm{mac}$ rotis from the western Himalaya and Hengduan Mts. was established in these latter two territories only following divergence from Bhutanese pikas.

ACKNOWLEDGMENTS. We thank D. Lunde (Washington); A. Averianov, G. Baranova and O. Makarova (Saint Petersburg); P. Jenkins (London); R. Angermann (Berlin); Q. Yang, L. Xia and D. Ge (Beijing); X. Jiang, K. He and S. Li (Kunming); W. Li (Xining); G. Sharma and V. Kumar (Kolkata); E. Westwig and A. Marcato (New York); C. Conroy (Berkeley); and B. Patterson and W. Stanley (Chicago) for the opportunity to study collections under their care, and for their invaluable help. We thank E. Bragina (Raleigh) for providing helpful information. This study was supported by the Russian Science Foundation, grant 14-50-00029; data collecting for the morphological portion of the work was supported by the Russian Foundation for Basic Research, grant 14-04-00163 and research project of MSU Zoological Museum (AAAAA16-116021660077-3).

\section{References}

Campos P.F. \& Gilbert T.M. 2012. DNA extraction from keratin and chitin // Ancient DNA: Methods and Protocols. P.43-49.

Chen X. \& Li W. 2009. A new subspecies of Ochotona forresti in southeastern Tibet, China // Acta Theriologica Sinica. Vol.29. No.1. P.101-105.

Dahal N., Lissovsky A.A., Lin Z., Solari K., Hadly E.A., Zhan X. \& Ramakrishnan U. 2017. Genetics, morphology and ecology reveal a cryptic pika lineage in the Sikkim Himalaya // Molecular Phylogenetics and Evolution. Vol.106. P.55-60.

Feng Z. \& Zheng C. 1985. Studies on the pikas (genus Ochotona) of China - taxonomic notes and distribution // Acta Theriologica Sinica. Vol.5. No.4. P.269-290.

Ge D., Lissovsky A.A., Xia L., Cheng C., Smith A.T. \& Yang Q. 2012. Reevaluation of several taxa of Chinese lagomorphs (Mammalia: Lagomorpha) described on the basis of pelage phenotype variation // Mammalian Biology. Vol.77. No.2. P.113-123.

Hijmans R.J., Cameron S.E., Parra J.L., Jones P.G. \& Jarvis A. 2005. Very high resolution interpolated climate surfaces for global land areas // International Journal of Climatology. Vol.25. No.15. P.1965-1978.

Hoffmann R.S. \& Smith A.T. 2005. Order Lagomorpha //
Wilson D.E. \& Reeder D.M. (eds.). Mammal species of the world: a taxonomic and geographic reference. $3 \mathrm{rd}$. ed. Baltimore, MD: John Hopkins Univ. Press. Vol.1. P.185-211.

Irwin D.M., Kocher T.D. \& Wilson A.C. 1991. Evolution of the cytochrome $b$ gene of mammals // Journal of Molecular Evolution. Vol.32. No.2. P.128-144.

Jobb G. 2011. TREEFINDER version of March 2011. Munich, Germany.

Kircher M., Sawyer S. \& Meyer M. 2012. Double indexing overcomes inaccuracies in multiplex sequencing on the Illumina platform // Nucleic Acids Research. Vol.40. No.1. P.1-8.

Kocher T.D., Thomas W.K., Meyer A., Edwards S.V., Pääbo S., Villablanca F.X. \& Wilson A.C. 1989. Dynamics of mitochondrial DNA evolution in animals: amplification and sequencing with conserved primers // Proceedings of the National Academy of Sciences. Vol.86. No.16. P.6196-6200.

Lanier H.C. \& Olson L.E. 2009. Inferring divergence times within pikas (Ochotona spp.) using mtDNA and relaxed molecular dating techniques // Molecular Phylogenetics and Evolution. Vol.53. No.1. P.1-12.

Leonard J.A., Wayne R.K. \& Cooper A. 2000. Population genetics of Ice Age brown bears // Proceedings of the National Academy of Sciences. Vol.97. No.4. P.16511654.

Li H. \& Durbin R. 2009. Fast and accurate short read alignment with Burrows-Wheeler transform // Bioinformatics. Vol.25. No.14. P.1754-1760.

Lissovsky A.A. 2004. Contribution to age determination of pikas (Lagomorpha, Ochotonidae, Ochotona) // Russian Journal of Theriology. Vol.3. No.1. P.43-48.

Lissovsky A.A. 2014. Taxonomic revision of pikas Ochoto$n a$ (Lagomorpha, Mammalia) at the species level // Mammalia. Vol.78. No.2. P.199-216.

Martin M. 2011. Cutadapt removes adapter sequences from high-throughput sequencing reads // EMBnet Journal. Vol.17. No.1. P.10.

Mina M.V. \& Klevezal G.A. 1976. [Growth of animals]. Moscow: Nauka. 291 p. [in Russian].

Obolenskaya E.V., Lee M.-Y., Dokuchaev N.E., Oshida T., Lee M.-S., Lee H. \& Lissovsky A.A. 2009. Diversity of Palaearctic chipmunks (Tamias, Sciuridae) // Mammalia. Vol.73. No.4. P.281-298.

Pääbo S. \& Wilson A.C. 1988. Polymerase chain reaction reveals cloning artefacts // Nature. Vol.334. No.6181. P.387-388.

Rambaut A., Suchard M.A., Xie D. \& Drummond A.J. 2014. Tracerv1.6, Available from http://beast.bio.ed.ac.uk/Tracer.

Rohland N. \& Reich D. 2012. Cost-effective, high-throughput DNA sequencing libraries for multiplexed target capture // Genome Research. Vol.22. No.5. P.939-946.

Ronquist F., Huelsenbeck J. \& Teslenko M. 2011. MrBayes version 3.2 manual: tutorials and model summaries // Distributed with the software from mrbayes.sourceforge.net/mb3.2_manual.pdf. P.1-172.

Ronquist F., Teslenko M., Van der Mark P., Ayres D.L., Darling A., Höhna S., Larget B., Liu L., Suchard M.A. \& 
Huelsenbeck J.P. 2012. MrBayes 3.2: efficient Bayesian phylogenetic inference and model choice across a large model space // Systematic Biology. Vol.61. No.3. P.539542.

Schmieder R. \& Edwards R. 2011. Quality control and preprocessing of metagenomic datasets // Bioinformatics. Vol.27. No.6. P.863-864.

Smith A., Formozov N., Hoffmann R., Zheng C. \& Erbajeva M. 1990. The pikas // Chapman J.A. \& Flux J.E.C. (eds.).
Rabbits, hares and pikas: status survey and conservation action plan. Gland, Switzerland: IUCN. P.14-60.

Yu N., Zheng C., Zhang Y.-P. \& Li W.-H. 2000. Molecular systematics of pikas (genus Ochotona) inferred from mitochondrial DNA sequences // Molecular Phylogenetics and Evolution. Vol.16. No.1. P.85-95.

Zhang J., Kobert K., Flouri T. \& Stamatakis A. 2014. PEAR: a fast and accurate Illumina Paired-End reAd mergeR // Bioinformatics. Vol.30. No.5. P.614-620.

Appendix 1. List of specimens, analyzed in morphometric study. Localities are followed by Museum IDs. For abbreviations see Material and methods section.

\section{O. macrotis}

Nepal, E Everest (NHMUK 22.3.2.33, NHMUK 22.3.2.29, NHMUK 22.3.2.32, NHMUK 22.3.2.35, NHMUK 22.3.2.28, NHMUK 22.3.2.30); India, W Sikkim, Gomchen, $5 \mathrm{~km} \mathrm{~W}$ of Bakhim (ZSI 24221, ZSI 24222); Nepal, Head of Khumbu glacier near Great Ice fall 18000' W of Everest (ZSI 12391); Nepal, Kama Valley, Everest (NHMUK 22.3.2.23); India, Sikkim, Lhasar, $8 \mathrm{~km}$ NE of Thanggu (ZSI 24224); China, Doker la (NHMUK 14.10.23.33); China, Yunnan, Mekong Yangtze watershed, $28^{\circ} 28^{\prime \prime} \mathrm{N}, 9^{\circ} 6^{\circ} \mathrm{E}$ (NHMUK 22.9.1.140, NHMUK 22.9.1.141, NHMUK 22.9.1.143); China, Yunnan, Mekong Valley, $28^{\circ} \mathrm{N}$ (NHMUK 22.9.1.145); Nepal, Muktinath (NHMUK 55.80, NHMUK 55.86, NHMUK 55.87); Nepal, Barun River Valley, 3 mi SW Makalu (MVZ 119403); China, Xizang Rutog (NWIPB 0005106(74075)); China, Xizang, Burang Xian, Kejia (NWIPB 0005105(74140), NWIPB 0005107(74141)); China, Xizang, Chayu (BIZ 26845, BIZ 26854); China, Xizang, Dingri, vic. of Shajitang (BIZ 17849, BIZ 17848, BIZ 17846); China, Xizang, Dingri, Tamuqin (BIZ 17850); China, Xizang, Goqen (NWIPB 0005110(73175), NWIPB 0005112(73177), NWIPB 0005113(73176)); China, Xizang, Rutog, Rena (NWIPB 0005108(74080)); China, Xizang, Zayu Xian, Demula Mountain (NWIPB 0005109(73179)); China, Yaratsaga, Ta chien lu (=Kangding) (NHMUK 11.10.3.7); China, Yunnan, Adong (KIZ 79469, KIZ 79481, KIZ 79498, KIZ 79500).

O. macrotis duoxionglaensis

China, SE Xizang, Nam La, Kong bo, near Namcha Barwa (NHMUK 48.31); China, Xizang, Mainling Xian (NWIPB 0006340(79071), NWIPB 0006342(79072)); China, Xizang, Medog Xian, Duoxiong Mountain (NWIPB $0006341(77139))$.

O. macrotis gomchee ssp.n.

Bhutan, Bumthang, Kangra Pizum Chhu, Headwaters of Chamka Chhu (USNM 397219).

\section{O. forresti}

Burma, $28^{\circ} 8^{\prime \prime} \mathrm{N}, 9^{\circ} 24^{\prime \prime} \mathrm{E}$ (NHMUK 27.3.7.22); upper Burma, Adung Valley (NHMUK 38.7.19.22); Burma, Kachin, Nam Kui Mts, Adung Valley (FMNH 40952); India, (former) Assam, Di Chhu Valley, 2815”N, 97¹5”E (NHMUK 27.3.7.19, NHMUK 27.3.7.21, NHMUK 27.3.7.20); China, NW Yunnan, Lichang Ridge (NHMUK 23.4.1.91, NHMUK 23.4.1.92); N Burma, Mt Imaw Bum, Kachin (NHMUK 20.8.7.17); N Burma, Nyetmaw River (AMNH 115464); N Burma, Road to Chimeli Pass (AMNH 115466); upper Burma, Taron Valley, $28^{\circ} 10^{\prime}$ ”N, 981'ㄹ (NHMUK 50.717, NHMUK 50.718); China, Xizang, Chayu (BIZ 27132, BIZ 27133, BIZ 27134, BIZ 27135, BIZ 27136); China, Xizang, Linzhi, Chayu (SAF 02); China, Yunnan, Gongshan (KIZ 73114, KIZ 73122, KIZ 73147, KIZ 73148, KIZ 73185, KIZ 73187, KIZ 73835, KIZ 830340, KIZ 99154, KIZ 99171); China, Yunnan, Lisuzu, Gongshan (SAF 213 085, SAF 213 116); China, Yunnan, Lisuzu, Lushui (SAF 213 029, SAF 213 030); China, Yunnan, Lushui Xian, Yaojiaping (KIZ 200513); China, Yunnan, Lushui, Pianmà (BIZ f.n. 5009, KIZ 99283(CREDY97 183)).

\section{O. gloveri}

China, Xizang, Mangkang (KIZ 810400); China, Xizang, Baxoi Xian, Bamda (NWIPB 0005176(73191)); China, Xizang, Biru Xian, Xiaquka (NWIPB 0005118(78023)); China, Xizang, Gangpu Jomda Xian (NWIPB 0005194(73200)); China, Xizang, Riwoqe Xian, Leiwuqi (NWIPB 0005191(M35)); China, Xizang, Zuogong (BIZ 26852); China, Yunnan, Adong (KIZ 79745, KIZ 79756, KIZ 79770, KIZ 79774, KIZ 79776, KIZ 79778, KIZ 79788, KIZ 79789, KIZ 79790, BIZ 17726, BIZ 17727).

O. roylii

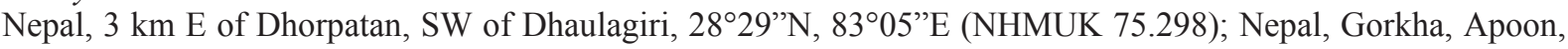
Sotidanda (ZSI 15431); Nepal, Gorkha, Barpak (NHMUK 23.11.5.49, NHMUK 23.11.5.51); Nepal, Bhairab Khund (NHMUK 1938.8.2.15); W Nepal, Garanphu, Seti Valley (NHMUK 54.1048); Nepal, Gosainkund (ZSI 
18492); Nepal, Gosainthan (NHMUK 37.3.14.33); NC Nepal, Gurka Nesum (NHMUK 1938.8.2.19); Nepal, Barun River Valley (MVZ 119401); Nepal, Camp 5, Arun Valley, 2738N 87¹5E (FMNH 114633, FMNH 114634); Nepal, E\#2, Dhobann, 6 mi NE of Those (FMNH 94087, FMNH 94088); Nepal, Newakot Dist., Gosenkunde (FMNH 104183, FMNH 104181); Nepal, Newakot Dist., Phulung Ghyang (FMNH 57786, FMNH 57788, FMNH 57789); China, Xizang, Nepal border, Ramjen (NHMUK 1938.8.2.18); Nepal, Gorkha, Satthar Hill (NHMUK 23.11.5.52); China, Xizang, Nielamu, Boqu valley (BIZ 25251, BIZ 25252, BIZ 25253, BIZ 25255); China, Xizang, Nielamu, Quxiang (BIZ 25254); China, Xizang, Nyalam (NWIPB 0005058(028)); China, Xizang, zhangmu (BIZ 26781, BIZ 26782, BIZ 26784, BIZ 26788, BIZ 26789, BIZ 26792).

\section{O. curzoniae}

China, North of Xizang (BIZ 17836); China, Xizang, Pedi (ZMB MAM 90896); China, Xizang, Tingri (NHMUK 22.3.2.36, NHMUK 22.3.2.38, NHMUK 22.3.2.42, NHMUK 22.3.2.37); China, Xizang, Amdo Xian (NWIPB 0004652(72037)); China, Xizang, Baxoi Xian, Bamda (NWIPB 0004635(73194)); China, Xizang, Damxung, Yangbajing (BIZ 26810, BIZ 26811, BIZ 26812); China, Xizang, Dazi (BIZ 26836); China, Xizang, Gangdise Shan (BIZ 26832, BIZ 26833); China, Xizang, Mangkang, 2 Km south of Mangkang county town (BIZ 32408, BIZ 32409, BIZ 32410, BIZ 32411); China, Xizang, Markam Xian (NWIPB 0004658(77118)); China, Xizang, Nangarze (Langkazi) (BIZ 17820, BIZ 17838); China, Xizang, Nielamu, Selong (BIZ 26840); China, Xizang, Pulan Xian, Anjia (NWIPB 0004634(74145)); China, Xizang, Pulan Xian, Mafamu Lake (NWIPB 0004633(74146), NWIPB 0004640(74148), NWIPB 0004662(74149)); China, Xizang, Shannan (NWIPB 0004695(77041)); China, Xizang, Shigatse (BIZ 26808); China, Xizang, Yadong, Pagri (BIZ 26823, BIZ 26824, BIZ 26825, BIZ 26829 , BIZ 26831); China, Xizang, Yadong, Pali (BIZ 26826).

\section{O. nubrica}

China, Xizang, Babgong Co (NWIPB 0004625(74044)); China, Xizang, Dangxiang, Yangbajin (BIZ 26793, BIZ 26796, BIZ 26799, BIZ 26801, BIZ 26804, BIZ 26806, BIZ 26807); China, Xizang, Garyarsa (NWIPB 0004615(74166)); China, Xizang, Lhasa (BIZ 24922); China, Xizang, Nyingchi Xian (NWIPB 0004584(730021), NWIPB 0004586(730020), NWIPB 0004587(730017)); China, Xizang, Pulan Xian, Barga (NWIPB 0004604(74157), NWIPB 0004605(74161), NWIPB 0004606(74160), NWIPB 0004608(74155), NWIPB 0004612(74154), NWIPB 0004619(74164), NWIPB 0004624(74151), NWIPB 0004626(74156), NWIPB 0004629(74162), NWIPB 0004630(74185)); China, Xizang, Zanda Xian (NWIPB 0004620(74124), NWIPB 0004621(74108), NWIPB 0004607(74109)); China, Xizang, Peyku Lake (ZMMU S-155352).

\section{O. thibetana s.l.}

China, Xizang, Zya Ha La Pass (USNM 255941); China, Chumbi Valley (NHMUK 25.3.21.2); China, Doker la (NHMUK 14.10.23.34); India, Sikkim, Gnatong (NHMUK 15.9.1.224, NHMUK 15.9.1.226, NHMUK 15.9.1.227, NHMUK 15.9.1.228, NHMUK 15.9.1.229, NHMUK 15.9.1.231); India, E Sikkim, Kyongnosla Alpine Sanctuary, $30 \mathrm{~km}$ from Gangtok (ZSI 24233, ZSI 24234); India, Sikkim, Lachen (ZMB MAM 90887, ZMB MAM 90888, ZMB MAM 90891, NHMUK 15.9.1.232, FMNH 35850); India, W Bengal, Darjeeling Distr., Sandakpur (ZSI 15959); India, Sikkim, W. Chungtang (ZMB MAM 90892); India, S. Sikkim, Maenam (ZSI 24235, ZSI 24237); India, Sikkim, Thanggu (ZSI 24223, ZSI 24225, FMNH 35851, FMNH 35856, FMNH 35853); India, N Sikkim, Yumthang (ZSI 24227, ZSI 24228, ZSI 24229, ZSI 24230); China, Xizang, Jiuzhi Xian (NWIPB 0004603(73212)); China, Xizang, Chayu, Guqin (BIZ 27126, BIZ 27127); China, Xizang, Linzhi, Chayu (SAF 31, SAF 32); China, Xizang, Linzhi, Gongbujiangda (SAF 0826 001, SAF 0826 002, SAF 0828 005, SAF 0828 006, SAF 0828007, SAF 0828 008, SAF 09 243, SAF 09 244, SAF 09 245, SAF 09 246, SAF 09 247, SAF 09 250); China, Xizang, Renqinggang (NẄIPB 000631̄̄(77024)); Chīna, NW Yunnan, Lichiang Ridge (NHMŪK 23.4.1.86, NHMUK 23.4.1.87); China, Yunnan, Mekong-Salwin Divide (NHMUK 22.9.1.157); China, Yunnan, MekongYangtze Divide (NHMUK 22.9.1.152); China, NW Yunnan, Sung Kwei Ridge (NHMUK 22.9.1.142); China, Yunnan, Adong (KIZ 79456, KIZ 79483, KIZ 79496, KIZ 79502); China, Yunnan, Baimaxueshan (BIZ 34434, BIZ 34435, BIZ 34436, BIZ 34437, BIZ 34438); China, Yunnan, Deqin (BIZ 17715, BIZ 17716, BIZ 17717, BIZ 17718, SAF MLXS356); China, Yunnan, Fugong (KIZ 78052); China, Yunnan, Lijiang (KIZ 220195, KIZ 220196, KIZ 220197); China, Yunnan, Lijiang, Yulongshan Baiekou (BIZ 17721, BIZ 17722); China, Yunnan, Shangri-la (KIZ 810219, KIZ 810220, KIZ 810221, KIZ 810222, BIZ 17709, BIZ 17707); China, Yunnan, Weixi (KIZ 810492, KIZ 810519, KIZ 810521, KIZ 810537, KIZ 810567, KIZ 810608, KIZ 810609); China, Yunnan, Xiaozhongdian (KIZ 1025, KIZ 810119, KIZ 810120, KIZ 810133, KIZ 810182, KIZ 810203, KIZ 810809); China, Xizang, 40 miles N of Chamdo town (ZIN 68914). 
Appendix 2. List of specimen's GenBank IDs analyzed in genetic study.

O. macrotis gomchee ssp.n. KX989538

O. macrotis JX682574, AF272988, KX989536

O. erythrotis AF272999

O. forresti AF272998, KX989537, KU359628, KU359627

O. koslowi AF272993

O. ladacensis JX682569, AF272992

O. roylii JX682573, AF 272997

O. rufescens AJ132206, JF911811

O. rutila JX682566

O. alpina HM346528, HM346527, EF567055

O. argentata AF272996

O. cansus AF273008, AF273003, AF273007, AF273005

O. collaris AF348080, EU549743, EU549742, EU549741, EU549739, EU549738, EU549737, EU549736

O. curzoniae EF535828, FJ227482, FJ227481, FJ227480, FJ227479, FJ227477, FJ227476, FJ227475, FJ227474, FJ227473, FJ227472, FJ227471, FJ227470, FJ227469, FJ227468, FJ227467, FJ227466, FJ227460, FJ227456, FJ227454, FJ227453, FJ227452, FJ227449, FJ227448, FJ227446, FJ227444, FJ227441, FJ227440, FJ227439, FJ227438, FJ227437, FJ227436, FJ227433, FJ227428, FJ227427, FJ227417, FJ227416, FJ227415, FJ227413, FJ227405, FJ227402, FJ227401, FJ227400, FJ227399, FJ227397, FJ227391, FJ227389, FJ227388, FJ227386, FJ227385, FJ227384, FJ227383, FJ227381, FJ227378, FJ227377, FJ227376, FJ227375, FJ227373, FJ227372, FJ227370, FJ227368, FJ227365, FJ227364, FJ227360, FJ227358, FJ227357, FJ227354, FJ227353, FJ227352, FJ227351, FJ227347, FJ227345, FJ227341, FJ227340, FJ227338, FJ227335, FJ227333, FJ227332, FJ227330, AF326273, AF273002, AF273001

O. dauurica AF273000, EF567059

O. hoffmanni JX682565

O. hyperborea HM366944, HM366943, EU549745, EU549744, EF567057, EF567054, EF567053, AF272994, $\mathrm{AB} 053257$

O. mantchurica EF567058, HM346529

O. nubrica JX682571, JX682572, JX682570, AF272991

O. pallasii HM366946, AF272990

O. princeps AJ537415, EU591094, EU591093, EU591086, EU591081, EU591080, EU591079, EU591073, EU591070, EU591065, EU591063, EU591062, EU591061, EU591059, EU591051, EU591050, EU591048, EU591046, EU591040, EU591032, EU591031, EU591030, EU591026, EU591020, EU591012, EU591002, EU591001, EU590998, EU590995, EU590993, EU590986, EU590985, EU590977, EU590974, EU590971, EU590969, EU590967, EU590966, EU590955, EU590950, EU590949, EU590947, EU590943, EU590942, EU590939, EU590935, EU590934, EU590929, EU590928, EU590925, EU590924, EU590923, EU590920, AF272989

O. pusilla JX682567, JX682568, HM366945

O. syrinx AF272995

O. thibetana JF911813, AF272986, JF911812

O. thomasi AF272987

O. turuchanensis EF567056

Pronolagus crassicaudatus AY292738

Pronolagus rupestris AY292735

Romerolagus diazi HQ596487

Oryctolagus cuniculus HQ596486

Pentalagus furnessi AB058606

Brachylagus idahoensis AY292721

Bunolagus monticularis AY292718

Sylvilagus floridanus AY292724

S. aquaticus AY292726

S. audubonii HQ596488

Lepus americanus JF489126

L. californicus HQ596466

L. europaeus HQ596474

L. timidus AY599075 